August 2010

\title{
The Opposition Front against Compulsory Military Service: The Conscription Debate and Human-Rights Activism in Post- dictatorship Argentina
}

Santiago Garaño

Follow this and additional works at: https://digitalcommons.usf.edu/gsp

\section{Recommended Citation}

Garaño, Santiago (2010) "The Opposition Front against Compulsory Military Service: The Conscription Debate and Human-Rights Activism in Post-dictatorship Argentina," Genocide Studies and Prevention: An International Journal: Vol. 5: Iss. 2: Article 5.

Available at: https://digitalcommons.usf.edu/gsp/vol5/iss2/5

This Articles is brought to you for free and open access by the Open Access Journals at Digital Commons @ University of South Florida. It has been accepted for inclusion in Genocide Studies and Prevention: An International Journal by an authorized editor of Digital Commons @ University of South Florida. For more information, please contact digitalcommons@usf.edu. 


\title{
The Opposition Front against Compulsory Military Service: The Conscription Debate and Human-Rights Activism in Post-dictatorship Argentina
}

\author{
Santiago Garaño \\ PhD candidate, Philosophy and Literature School, University of \\ Buenos Aires, Grant holder of the National Scientific and \\ Technical Research Center (CONICET)
}

Compulsory military service (CMS) was in place in Argentina from 1902 to 1995. Although its abolition was directly linked to the murder of soldier Omar Carrasco, the prosecution of this case of violence should not ignore the pre-existing opposition movement that developed toward the end of the last dictatorship (19761983). Within the context of a wider debate on the functioning of conscription, in November 1983 a group of human-rights activists launched the Opposition Front against the CMS (FOSMO). This article examines FOSMO's history, which offers insight into the hypothesis that, under certain historical and political circumstances, human-rights activists can not only contribute to debate but challenge and limit state violence through a series of political and legal strategies. The author analyzes the links (people, arguments, disputes) that FOSMO constructed, first, to question a strongly rooted institution in young men's socialization (and highly significant in the building of masculinity); second, to denounce not the "failures" or "excesses" but the logic of the operation and the values and violent practices that organized it; and, finally, to seek institutional channels to achieve the abolition of this compulsory system.

Key words: compulsory military service, freedom of conscience, human-rights activism

\section{Introduction}

Compulsory military service (CMS) was in effect in Argentina from 1902 to $1995 .^{1}$ That is, for almost 100 years, young men aged twenty (after 1977, aged eighteen), selected by drawing lots and declared physically and mentally "fit," received a period of military training through the Armed Forces. Although the abolition of CMS was directly linked with the murder of soldier Omar Carrasco (which occurred at a military base in the province of Neuquén on 6 March 1994), ${ }^{2}$ the active prosecution of this case of violence should not obscure the existence of a prior opposition movement that began toward the end of the last dictatorship (1976-1983). In November 1983, in the context of a wider debate on the functioning of conscription, a group of human-rights activists known as the Opposition Front against the CMS (FOSMO) launched its movement. Unlike other means of evading conscription (through legitimate channels involving military personnel), FOSMO became a political organization

Santiago Garaño, “The Opposition Front against Compulsory Military Service: The Conscription Debate and Human-Rights Activism in Post-dictatorship Argentina." Genocide Studies and Prevention 5, 2 (August 2010): 174-190. (C) 2010 Genocide Studies and Prevention. doi:10.3138/gsp.5.2.174 
that built a series of arguments challenging conscription based on the concept of "freedom of conscience." 3

In this article, I will show how, through the struggle initiated by Eduardo Pimentel (and focusing on FOSMO), the ongoing agenda of the human-rights movement was expanded. In this line of analysis, FOSMO's history offers insight into the hypothesis that, under certain historical and political circumstances, human-rights activism, through a series of political and legal strategies, can challenge and limit state violence. ${ }^{4}$ I will also show that human-rights organizations are not created or founded but acquire their unique identity through their singular political actions. ${ }^{5}$

\section{“Freedom of Conscience": A Family Decision}

During a press conference on 7 April 1983, Eduardo Pimentel, one of founding members of the Permanent Assembly for Human Rights (APDH), and his family announced their decision to stop their son Ignacio from complying with the CMS, protecting themselves through the exercise of the patria potestad-a parent's right to custody. The family's refusal to let their children comply with the CMS was linked to a broader debate at the end of the Malvinas (Falklands) War and the decline of the dictatorial regime: between 1982 and 1983, the continuity of conscription was one of the issues on the APDH's agenda.

Pimentel said that he had presented a legal document on 2 November 1982 and an annex addressed to the illegitimate president, Reynaldo Bignone, a few weeks afterwards on 13 January 1983. Pimentel pointed out that the legal contradiction between the CMS law, which "involves the child but not the father," and the idea that patria potestad refers to a minor's "guardian." He also alleged "religious, moral and political" reasons: "I teach my children in my family not to kill; so I cannot hand my son over to people who will teach him that his duty is to kill the enemy, when the gospel tells us that we have to love them."6

I intend to exercise the right of patria potestad, but what obliges me in conscience to act as I do is the right of a responsible parent, and primarily before God and before men, that comes to us in a divine and natural way... Our responsibility as parents obliges us to be coherent and not to contradict ourselves, to bear witness to our faith and our thinking ... How, then, can we combine all due respect for parents and teenage behavior when he or she sees that such respect has not been respected? Deciding to kill a man is a serious problem of conscience. If your parents say, "You shall not kill," and the state orders you to "kill the enemy," both of which are imposed on the youth, what comes next? ${ }^{7}$

However, Pimentel said, together with these moral and religious reasons, the legal arguments became an excellent resource to encourage a debate within the judicial system: "It is the first time that a case of this kind has been presented ... My conclusion, based on Article 275 of Velez Sarfield's code, is different. It explicitly mentions patria potestad when deciding whether the child will or will not comply with the CMS." 8 After this press conference, Ignacio Pimentel was summoned to the Military District on 18 March, where Colonel Lujan informed him that the commander in chief had ruled that "custody" extended only to volunteers and not to those required to comply with the CMS. In light of this ruling, Ignacio was called to appear for his medical examination and his subsequent enlistment in March. Eduardo explained that when the order came, the entire family made a decision and accompanied Ignacio to the regiment: 
When we arrived ... we had a verbal confrontation with a lieutenant colonel ... The point is that after arguing heatedly for about ten minutes, the lieutenant colonel informs me that they will keep Ignacio. Imagine my reaction. I said, "You have all the power to trample on my patria potestad and contradict my decision, but I assure you this is very serious and I will not give up my struggle." I left the place and initiated a fast; my wife followed. After two hours, my son called home to announce that he had been exempted "owing to a physical problem." I do not really care about the actual reasons why the ruling military district managed to reach that resolution. The thing is that they have done it; they have respected my authority as a parent. ${ }^{9}$

Faced with this "abnormal" case (the appeal to "custody" and "freedom of conscience"), and to avoid a more serious conflict, the military authorities attempted to use a well-known mechanism to "exempt" Pimentel's son by declaring him "unfit" during the medical examination. Despite the military authorities' decision, Eduardo Pimentel took his case to the prosecutor: "I am conducting a thorough study of the subject with two attorneys to determine the reasons for the opposition [to the CMS]" and, by bringing the issue to a non-military environment, let them be "the judges [who] respond to our questions." 10 In this sense, Pimentel stated, "It is a paradox that the patria potestad enables parents to prevent their children from pursuing a military career but is useless when an entire family opposes a young man's conscription." 11 Not satisfied with the outcome of his son's case, he launched a movement for "freedom of conscience." The goal was for his son's case to have a multiplier effect-to have a strong political impact rooted in the exercise of freedom of conscience.

This article assumes that the concept of "human rights" is not meaningful enough in the abstract and that how this notion is translated in practice depends on power relations forged in local contexts. ${ }^{12}$ That is, while human rights is in theory a self-proclaimed universal value, it is in fact culturally and politically interpreted and can be modified so that its meaning depends on how the concept is politically articulated in specific contexts. ${ }^{13}$ In Argentina, the conformation of the human-rights movement has not only built a series of demands on the systematic violation of human rights during the last dictatorship but also played a central role in defining the term "human rights." 14 During the first years of Argentina's democratic transition, the issue of human rights was intimately tied to the "problem of the disappeared" during the last Argentine military dictatorship. ${ }^{15}$

The human-rights movement was a heterogeneous group of social figures that actively encouraged resistance against the state violence, penal persecution, and social condemnation generated during the dictatorship. In this way, the movement actively reported and denounced the conformation of the terrorist state ${ }^{16}$ structured by the Doctrine of National Security (DNS) ${ }^{17}$-and the kidnappings and disappearances of people as a repressive modality executed clandestinely by the military forces. ${ }^{18}$ One of the acts denounced by the human-rights movement was the disappearance of conscripts during the last dictatorship: in 1982, the Center for Legal and Social Studies (CELS) documented the disappearance of more than 100 soldiers conscripted under the CMS. Even though the military authorities explained the absences as off-duty days, "releases," absences without leave, or "away on official business," applying the administrative procedure for cases of "desertion," CELS demonstrated that the missing soldiers had been kidnapped by the military forces and that most of them were still missing. ${ }^{19}$ 
Pimentel, in his struggle to abolish the CMS and to promote freedom of conscience, sought to extend the boundaries of what are socially understood as violations of human rights. Although the complaint was associated with the systematic disappearances of conscripts between 1976 and 1983, Pimentel attempted to expand the universe of issues and problems that the Argentine human-rights agenda had to incorporate, analyze, and legitimize for society in a post-dictatorship context.

His struggle can be understood only within the context of the transition to democracy and the previous experience of the human-rights movement against state terrorism and its crimes. This movement no longer existed, but it gave citizens the tools to challenge state violence, together with a series of political and legal strategies and political experiences to endow it with authority and prestige.

In Argentine human-rights organizations, the figure of the relative was central. "Putting forward primordial bonds (initially seen as 'non-political,' as they are their own bonds in the private sphere or the domestic arena) managed to legitimize their spaces in public intervention." 20 In this sense,

the dictatorship claimed a family discourse intended to assign parents an individual responsibility for the safety of their children-whom the terrorist state itself was killing and making disappear-privatizing in this way families' responsibility to safeguard and control their children. By positioning and referring to themselves as "relatives," the human-rights activists politicized their family bonds with the victims. ${ }^{21}$

In the case of the struggle Pimentel initiated, we also see a father invoking the status of relative to legitimize his claim, appealing to freedom of conscience as a way to prevent his son from complying with the CMS. However, in this case the person who began this conflict was a male parent; by contrast, the majority of relatives initiating human-rights organizations have been women, self-defined as "mothers." 22 This is because, until 1985, patria potestad was the right of men or, in the case of women, the right of single mothers and widows. ${ }^{23}$ However, other factors may explain the appeal of the father's position, which gave rise to new meanings and resistance methods. This strategy was also part of the previous experience of the human-rights movement, which had succeeded in appropriating, giving new meaning to, and rejecting the traditional family model in the discourse of the last dictatorship. ${ }^{24}$ This model-in which the family was the basic unit of the nation, and the nation was conceived of as the "big family"-linked the social structure to the biological order, giving natural characteristics to roles and social values:

The concept of the nation as a family ... led to a definition of the political relationship between the state and citizens as family members, so that citizenship rights and duties were replaced by filial obedience. The official discourse painted citizens as immature children who needed the guidance of a firm father. This nation-family model followed the traditional Catholic model ... [in which] the father is the head of the family and the mother is the one who both nourishes the family and safeguards traditional values. ${ }^{25}$

Pimentel added that the appeal to this series of moral values also questions the foundations of the armed forces' family model. Máximo Badaró, in his research on the National Military School (NMS), explains that "the use of the family metaphor allows us, in turn, to invoke a model of social relations that positions the Army as the 'protective father' or 'guardian' for the whole of Argentinean society." 26 
The military family that is recreated in the NMS is a patrilineal family in which children must obey and imitate the father. The freshman enters a model of social organization that represents positions associated with the figure of a father who holds the power to transmit knowledge and punishments and with subordinate positions associated with the place of the children. ${ }^{27}$

So it was the "father" and "the guardian of your children," and not a mother's place, that gave Pimentel the authority and prestige to challenge compulsory conscription while opening up an area of dispute to explain what that role meant socially.

As noted in subsequent reports to Pimentel, the arguments against the CMS's requirement were enriched by the Christian interpretation of violence, the defense of the family, the patria potestad, and a series of anti-war and pacifists arguments: "Through acts of war, the youth are taught a kind of historical linkage. This occurs in the majority of educational, military, and non-military institutions ... In Christianity, which is my faith, but also before and after, these anti-war testimonies have taken place." 28 Another issue was the criticism of the inculcation of a male warrior mentality:

Therefore, military institutions should be integrated with people with vocation. I do not say professionally, because this professional definition includes concepts of military effectiveness that I reject. What I want is a guardian of weapons; the soldier should guard the weapons, not to kill but to prevent from killing, to prevent their use and for the prevention of injustice, such as we suffer today. ${ }^{29}$

However, rather than "conscientious objection," Pimentel preferred to call his son's and his family's attitude "freedom of conscience": "The freedom of the young, and of the family. I have relied on this family right, which is a basic state institution, recited as such, but unknown regarding the facts ... This family institution has to be effectively recognized." 30 He later wrote that

freedom of conscience, conscientious objection, enshrined by the Second Vatican Council, "everyone should consequently follow their conscience," tells us that we cannot obey any order, and much less so those concerning murder. Thus, the CMS law is immoral according to Vatican II and commits an outrage against human rights. ${ }^{31}$

Once the Pimentel family's decision had been made public, other parents and young people followed their strategy. Stojan Tercic, father of Alejandro, communicated his decision not to authorize his son's compliance with the CMS to the illegitimate president, protecting himself with the exercise of patria potestad. In the letter he sent to the de facto president, he argued, "According to my conscience and exercising the patria potestad, I have decided not to allow my son Alejandro to answer the call for conscription. My decision is based on the belief that the CMS is opposed to God's law, which says 'Thou shall not kill,' and there is no law above God's law." 32 Fernando Angel Portillo, father of a young man from the 1965 military service cohort, sent a letter to the constitutional president, Raúl Alfonsín, explaining his opposition to his son's compliance with the CMS, based on the principles of the Constitution, the Universal Declaration of Human Rights, and "my Christian conscience's mandate." 33 At this point, and with the constitutional authorities in office, Portillo was the fourth father to appeal to patria potestad to prevent his son from complying with the CMS. 


\section{FOSMO: From Family Decision to Political Struggle}

Thanks to the impact that these cases acquired, on 13 November 1983, after the presidential elections of 28 October (the constitutional government was to take office on 10 December), FOSMO was constituted-conceived as a "pluralistic and ecumenical" institution seeking to concentrate persons and celebrities, groups and organizations, whose purpose was to fight for the abolition of the CMS. To replace the requirement of military service, they proposed "substitute activities, such as a social or civil service controlled by other sectors of the state and not by the armed forces." 34 These would have the advantage of offering new ways to socialize and "shape" Argentine youth in the light of the new "problems" that the country was facing. Santiago Kovadloff, philosopher and member of FOSMO, argued in favor of an "optional service" and enumerated the benefits of implementing this new system:

An adult ... is one who, in essence, is already in a position to decide what is good and what is not good for him. He should not be deprived of the opportunity to comply with the CMS, if desired. But there is no reason to force him to do it ... If any obligation must now govern civilian and military conduct, it is that of acquiring, primarily, a substantial republican training in order to enable them all equally to consolidate the democratic demands of today. ${ }^{35}$

In FOSMO's founding document, the first area of dispute was the interweaving of violent practices involving what the CMS had accomplished and its relationship with the male morality of war that, during the twentieth century, had permeated Argentinean society. While denouncing the soldier's subjugation to a "regime of severe discipline with physical, mental, and moral violence" by military personnel (with no real chance of repelling the arbitrary and humiliating acts of which he is the object), FOSMO questioned the adoption of a "military mentality, with a different and even opposite code of values to the rest of society," that led to an "obsessive cult of military values." However, far from denouncing the violence as an excess or a problem of the people in charge of the institution, they criticized the "structural character" of the institution, whose purpose was to "intervene in the social body":

CMS's characteristics do not arise as a consequence of the institution's malfunctioning. On the contrary, they are the result of one of the main aims that was assigned to it at the time of its creation in 1901. Indeed, those who designed the current system assigned the CMS two main functions: one, to constitute a school for the citizenry's morality, turning the army into "a powerful instrument to create public morality"; and the other, to act as an antidote against cosmopolitism in a society composed of immigrants and the children of foreigners. ${ }^{36}$

In a document published by FOSMO, Pedro Vendramin, another member, analyzed the CMS's creation in 1901. He quotes Mariano Demaría, a congressional representative, in reference to a talk at the Military Academy in 1915 by Manuel Carle: "The officer feels that the nation has entrusted him with the redemption of the uneducated, ignorant, and evil conscript, who is an Argentinean at birth but barbaric with respect to his condition, which is a threat to social stability and a threat to our culture." 37

In fact, it targeted the cabecita negras, ${ }^{38}$ the indigenous populations, and the children of immigrants. It was about straightening out ideas or injecting nationalism to supposedly stateless people or to the children of European exiles like anarchists. And so, generation after generation, thousands of conscripts joined the army or navy-the 
air force appeared much later [in 1950]—and, in this way, military society counted on the military service requirement to keep young people within its grasp, in order to teach them a value system that threatens civil institutions and the values of the people and that leaves the Constitution defenseless, and to provoke a series of seditious acts aimed at overthrowing several governments. ${ }^{39}$

Soldiers were not "simple civilians who had to be instructed in warfare but foreigners who had to be nationalized, barbarians who had to be civilized. This 'nationalization' really only served to tame them, discipline them through different violent practices, 'subdue the soldier' (a phrase repeated in the barracks), by teaching discipline with 'non-pedagogical' methods, military training, long walks, physical punishment ..., automatic responses, loss of personal identity, uniforms...."40 The slogan "subordination and courage" should be interpreted as "subordination to the whims of the uniformed professional" and denounced: this progressive loss of rights permeated the "violent methods" which were applied to soldiers and led to the deaths of some conscripts. Another FOSMO member, Alfredo Grande, highlighted the fact that FOSMO's work was no longer to seek exceptions to the rule but, rather, to modify the rule, and invited others to join this movement: "You will fight for your child, but not just for him." 41

Because the CMS was actually a long-term bureaucratic institution, with its own structures, constitution, and organization for its members, norms, and rules, ${ }^{42}$ what the FOSMO wanted to do was to reveal the continual management that conscripts had to put up with, whether under a dictatorship or in a democracy. They thus demonstrated that from the beginning, the compulsory military system had the effect of normalizing military discipline throughout society, so that the punishments delivered in the barracks were seen as a normal part of military discipline: ${ }^{43}$

Control over time and movement helped to discipline bodies during long waiting periods that encouraged a false immobility, forced marches, fast runs, the rigid schedule that deliberately cuts the most intimate times; the acceptance and approval of nonsensical orders that block critical thinking are the procedures imposed by every military hierarchy. ${ }^{44}$

\section{FOSMO's Opposition}

This active movement involving the CMS generated various forms of opposition to FOSMO. For example, Edward Siutti wrote a letter to the editor of the newspaper Tiempo Argentino in March 1984:

I think like my sons' father and like my father's son that to die to defend a piece of my country, regardless of who the ruler is, however small and insignificant it may be, is perhaps the best death which any well-born man can claim. Of all the opinions the only one worth highlighting is that of Eduardo Pimentel ... Not only is he, and I give good value and weight to what I say, a COWARD, but from his cowardice a coward's family discourse emerges, and he intends to make it public, urging the youth, who are already confused, to the most ignoble desertion ... Peace is a major achievement, but not at the expense of honor. And for a true patriot, national honor and one's own honor are the same thing. ${ }^{45}$

As this excerpt shows, the authorized position from which to defend the CMS was that of "my sons' father and my father's son," a "well-born man" (a man who could aspire to a "heroic death" in battle). A man-even the father of sons-who opposed conscription was a "COWARD," a man whose masculinity was deeply questioned. Eduardo 
Pimentel wrote a lengthy letter, published in the same newspaper, in which he took a clearly anti-war stand and highlighted the naturalization of military socialization among Argentine youth: "My principles are different. I do not kill and will not kill any man ... War is a crime, every war is unjust, and those who cause it are criminals." 46

Members of civil society strongly questioned the human-rights movement when it began to focus on the treatment of conscripts, who continued to be tortured and degraded and who had become the objects of state violence even under democratic government. This opposition arose because the movement dared to challenge a strongly rooted institution, in existence for more than eighty years, that also represented a highly meaningful experience for significant sectors of society. Since its creation in Argentina, large proportions of society considered conscription a rite of passage into male adulthood through the inculcation of a warrior mentality. At the same time, it played a role in the sense of belonging to-or exclusion from-the Argentine nation. Being a "man" and (therefore) being an Argentinean citizen (hypostatized in the fetish of having a libreta de enrolamiento, an identification card for men) were conditions that had been obtained by fulfilling the "duty" of military service (having first been declared "fit"). By surviving and living through this experience, one obtained this dual status.

However, other sectors in society made concerted efforts to avoid military service: to "escape" the draw, to be declared "unfit" in the medical examination, or to become conscientious objectors (e.g., the Jehovah's Witnesses). Others tried to pay off military and medical authorities to make exceptions or be declared unfit, or to ease their way through military training through friends or close connections with military personnel. Among other reasons, conscription had become a space where soldiers were often used in a domestic capacity by the military_giving rise to the term "co-lim-ba," short for corre-limpia-barre ("run, clean, sweep"); state violence was naturalized or was considered "a waste of time."

Thus, questioning this ritual was tantamount to challenging the virility of those who fell under criticism. This was so because, as Henrietta Moore stresses, Western discourses about sexuality and gender construct women and men as different types of people. In Western cultures, Moore writes, "male sexuality and persons of the male gender are portrayed as active, aggressive ... and powerful; while female sexuality and persons of the female gender are seen as essentially passive, powerless, submissive, and receptive." 47 These powerful dual discourses permeate society, and those who question them can be accused of not fulfilling the roles, attitudes, and daily socially constructed (self-)representations assigned to men and women. This explains the disparagement of Pimentel: being catalogued as a "coward" was synonymous with being passive, weak, submissive, and feminine.

Against this active debate, the commander-in-chief of the Army published an annex to the Revista de Educación Militar in which he posited that the war for "our" Malvinas Islands (in which a volunteer army had faced a conscripted army) had raised the issue of "replacing our current conscription system with a volunteer system to fill the ranks" for the armed forces, politicians, and society to consider. It was felt that the mandatory system had worked "with particular effectiveness" for eighty years and that it maintained its "validity" and was suited to "modern principles." His final conclusions harshly questioned those who opposed the CMS: 
(e) In light of the analysis of global trends, the references that are currently heard from those who are promoting the merits of volunteer services ... are far from real.

(f) The experiences of some countries that have opted for voluntary service ... highlight the breakdown of discipline, the high costs that the system involves, and, in particular, the danger that citizens lose interest in national defense.

It does not appear logical or desirable for our country that its adoption be advocated under the exclusive influence of a "Malvinas Syndrome" at this time.

While recognizing that not "everything must be kept as it is" and that there were "many aspects that can and must be improved," the article damned those who criticized the operation of the CMS:

Finally, on a subject in which everyone feels empowered to express opinions and value judgments, today, more than ever, the old proverb holds: "SPEAK LITTLE ABOUT WHAT YOU KNOW AND NOTHING ABOUT WHAT YOU DO NOT KNOW." 48

\section{The Launch: "Every war is unjust"}

On 6 August 1984 at 5 p.m., the thirty-ninth anniversary of the Hiroshima bombing, the members of FOSMO held a demonstration at the Plaza de los dos Congresos to "abolish the CMS." It was the launch of FOSMO at the doors of the Congress. The slogans read "For freedom of conscience", "For the right of families to educate their children", and "For the demilitarization of society", "For more food for the world and fewer weapons of war." Clearly, FOSMO did not define themselves as conscientious objectors but were fighting for "freedom of conscience"; they appealed to the right of the family to challenge the CMS and consolidated their pacifist and anti-war stance. This was the pillar on which the opposition rested.

The main speaker was Eduardo Pimentel, who also presented the main points of the petition ${ }^{49}$ that would be read before the National Congress:

We, the Opposition Front against the CMS, have adopted the abolition of the CMS as our only goal. And for several reasons: because the CMS upholds the institution of slavery, and this cannot be, because it has been abolished. We call for its abolition because we want the freedom of conscience to be respected, the freedom of each person. The liberty of parents who have borne men to educate them as their conscience commands and not as mandated by the politicians in power; this is real, and this is what I demand: "no one, no instrument, warlike as it may be, is going to tread on my rights." 50

On 9 August, three days after the demonstration, Eduardo Pimentel died at the age of sixty-one. Three of his sons took up his struggle. That is, a father's struggle for freedom of conscience was ultimately inherited by three of his children. In its Bulletin of October 1984, FOSMO wrote to the then president,

We are on the same path, the path Eduardo Pimentel began when he turned his back on his two sons' call for conscription. And we will follow that path. Although some think that Eduardo cannot guide us any longer, they are wrong. The true guide is an idea, generous and just ideas. Beyond death, they shall live. In those who make these ideas their own, developing them and taking action. In this regard, we have all been their children and will continue to be. 


\section{The Deaths of Conscripts}

One of the first members of FOSMO was Eudoro Palacio, whose son Mario Daniel, a conscript of the 1964 cohort, died on 24 April 1983 in the Artillery Regiment Los Polvorines at the age of eighteen. The army's official version was that he died from "non-traumatic cardiac arrest resulting from liver and kidney failure," but his companions had a different version: "He died after a savage beating at the hands of several officers. He was tortured, according to witnesses, and received no medical treatment." 51 For FOSMO, however, Mario Daniel's case was not the only one to be analyzed; it was incorporated into a broader complaint about everyday CMS routines: "Physical abuse in the CMS is the rule rather than the exception," as some claimed, "and the deaths of soldiers" were rarely made public.

But nobody can tell us that these are accidents or the defects of a system that needs correcting. We hold that all the deaths and violence are the inevitable result of the system. The inevitable result of the need to "bend," to teach young soldiers "subordination and courage." The inevitable result that occurs when some young men do not accept humiliation or gratuitous violence, or when their bodies just do not tolerate that particular way of "making us men." 52

In Vidas Precarias, Judith Butler discusses the characteristics of a particular form of violence, that which targets "unrealistic lives." Butler suggests that in certain social contexts and under certain historic conditions, certain deaths are more painful than others, while other lives that are far from protected are more vulnerable. This invisible and naturalized type of violence is aimed at a set of lives that are not considered worthy of attention or worth preserving. The violent termination of such lives does not leave traces, because such deaths are not socially recognized as losses and therefore do not merit an obituary or public mourning, since they do not fit the dominant cultural framework of "human." 53

If the possibilities of publicly authorized mourning reveal the rules that produce the "human," this differential distribution of grief makes it possible to render invisible the effects of state violence. ${ }^{54}$ That is, there is a relationship between the violence that puts an end to these lives, the definition of a universe of beings recognized as "human" (and some others that are not), and the prohibition of public mourning. Butler seems to say that extreme violence by the state, quiet, natural, and even desired, can legitimately be exercised against those who have previously been stripped of their status as "human" (or as "citizens"?).

In this line of analysis, grief is not only the means by which a life becomes, or stops being, a life to remember painfully but, at the same time, gathers and recreates the national political community as it reveals the ties that bind us to others and that make us who we are. Butler argues that we are constituted by those deaths that we remember painfully, as well as by the deaths that we repress, those faceless anonymous deaths that make up the gloomy background of our social world. ${ }^{55}$ For her, the challenge lies in recognizing the vulnerability and suffering of others (unevenly distributed throughout the world) and in taking collective responsibility for these lives and those deaths.

Butler constructs a national community with differential rights, lives, and deaths that are more or less worthy, bodies that are more protected and those that are vulnerable to state violence. However, as we see in the Eudoro case, Butler's argument opens the door for activism and social mobilization: it removes the anonymity of these deaths by means of a political struggle. FOSMO's battle for public recognition 
of those unreal deaths made grief public; it proved itself as an effective mechanism to expand the boundaries of citizenry and the meaning of "human" (and, in that movement, the category "human rights").

\section{The Bill}

Despite this extensive debate, FOSMO's mobilization, and the electoral promises of the Radical Party, there was little change in the functioning of the CMS between 1983 and 1984. The Executive Power (EP) sent Congress a bill proposing an exception to the CMS where compliance was "incompatible" with "clear imperatives of moral conscience and religion." Those exempted would be required to carry out some form of civil/community service for no less than one year under the coordination of an ad hoc committee.

Accompanying the EP's proposal, FOSMO sent Congress a document containing another bill on "conscientious objection," based on their analysis of the official proposal. FOSMO's members argued that "conscientious objection is not 'just a state of morally valuable affairs' (as the message that accompanies the project ... states), but a strict moral right of citizens as stipulated in the Constitution..." The FOSMO document contained a significant systematization of the arguments opposing the CMS and a refinement of the civil/community service proposal:

Conscientious objection does not intend to repeal the CMS but to repeal its compulsion, at least with respect to those for whom this service creates a serious conflict of conscience. It is about solving legitimate subjective situations that are covered in the spirit of the Constitution, of the Universal Declaration of Human Rights, and of the Treaty of San José de Costa Rica, of which our country is a signatory.

Conscientious objection seeks not a privilege but justice, the exercise of a right. It is not a dispensation of a public charge but a substitution of the content. Instead of military service, a no less arduous civilian service, and, never lacking in our country, as in any nation in the world, a field to serve for the purpose of a common good. ${ }^{56}$

The matching of the two types of service was intended to avoid "all kinds of discrimination" and "any action which may appear punitive" by the military; on the other hand, it was also intended to "ensure ... that it would not be used fraudulently to evade constitutional duties." Thus, "conscientious objection" and "civil service" would "benefit the social community and the citizens themselves." 57 In an interview with the newspaper La Voz, Defense Minister Horacio Jaunarena stressed that from 1983 the number of conscripts in the combined forces had been reduced (from 70,000 to 35,000$),{ }^{58}$ as had the probationary period for new conscripts. The "decompression of the international situation due to the diminishing possibility of impending conflicts does not mean that we are defenseless," Jaunarena said, "but it allows us to plan our defense in a more orderly and rational way." 59

However, it opposed the idea of an army composed solely of professional soldiers: "In an economic situation like ours it is very difficult to build a fully professional armed forces ... Personally, I believe that our CMS can be improved and that before moving from one system to the other, it is necessary to carry out a good analysis of recruitment costs." 60

The EP administration sent Congress the CMS exemption bill on 20 August 1984. Five years later, the newspaper Nuevo Sur questioned the EP's decision to "freeze" any modification of the CMS that might "irritate" the military. ${ }^{61}$ This situation was even more paradoxical: on 10 March 1988, the Argentine state voted for a 
resolution by the UN Human Rights Commission that called for states to recognize "conscientious objection" as a legitimate exercise of the right of freedom of thought, conscience, and religion "and recommended the elaboration of a law including ways to participate in civil service." 62

Between 1984 and 1989, bills to regulate changes in the CMS multiplied, but all met the same fate: they were not debated in Congress. The initiative was taken up by the Christian Democrats' congressional representative, Alberto Aramouni; he presented a bill on 21 June 1988 that contemplated a "community and alternative social service." This bill was opposed under pressure from the Ministry of Defense, however, which also blocked a debate of peronista Carlos Ruckauf's bill on the temporary reduction of the CMS. ${ }^{63}$ A senator from the Radical Party, Antonio Berhongaray, sought the Army's opinion on a proposal he had presented that would exempt "conscientious objectors." According to the newspaper Página 12, hours before the Defense Committee issued an opinion on this project, Lt. Col. Ricardo Emilio Degiampietro-the "link" between the Army and Congress-went to Berhongaray's office with a three-page top-secret report, unsigned and typed on paper without letterhead. ${ }^{64}$ A partial list of arguments against those who opposed the CMS was published in the newspaper:

- The pseudo-religious arguments are fallacious.

- The fulfillment of citizens' military obligations is not only not opposed to but fully reconciled with the Catholic faith.

- The proposal reflects an ideological view that works against the interests of the Republic.

- Unfortunate are those whose social conscience is being undermined by ideologues who, under the guise of pacifism, seek to disarm societies materially and spiritually so they can be conquered by evil atheistic ideologies that promote disarmament ...

- Holding positions that lead to national vulnerability, particularly if they are mediated by national legislators, would signify "treason to the nation" and be an affront to the memory of all those who shed their blood for it.

- We should ask ourselves what the fate of our country would have been if its finest sons, in the darkest hours of the Republic, who came to live or die for, had allowed for conscientious objection.

- It would imply the subordination of an essential and indispensable requirement-the CMS— to a quite subjective fact ("a supposed deep religious, philosophical, or moral conviction") that is impossible to confirm.

- Those who favor the objections should be reminded of the words that Boabdil's mother pronounced after the fall of Granada to Christian troops led by Catholic monarchs in 1492: "Weep like a woman for what you could not defend as a man." 65

This situation revealed how strongly some members of the military corporation resisted implementing any changes to the CMS and, in particular, their unwillingness to recognize the issue of "conscientious objection" as a collective and political way to circumvent the CMS. Understanding that FOSMO's goal was not to protest "excesses" but to question the very logic of the way this institution functioned, the military corporation once again resorted to gendered language to challenge criticism and legitimize their interests ${ }^{66}$ _ "Weep like a woman for what you could not defend 
as a man"- portraying women as signifying weakness (crying) and men as warriors (who know how to defend themselves from foreign enemies).

\section{The Portillo Case}

Fernando Portillo, among the first members of FOSMO, had tried to prevent his son, Alfredo, from complying with the CMS by invoking the patria potestad. According to Fernando, he had heard that his friend Eduardo Pimentel had presented an appeal to prevent his children from complying with the CMS. He sent a letter to President Raúl Alfonsín justifying his decision:

We do not emphasize the religious aspect; our principle is a moral one. We resist our children's being instructed in the use of weapons and prepared to kill fellow human beings, whatever their religion. That is why we rely on Articles 275 and 276 of the Civil Code, which clearly express ... that children cannot leave home to enter the military without parental consent. The following stipulates that if the children leave the parental home, authorities can be asked to send them back. ${ }^{67}$

Following his father's letter to the president, Alfredo Portillo received a letter summoning him to appear at the offices of the Military District of Buenos Aires under penalty of punishment. He did not do so. Once the administrative decision to enforce the CMS was noted, Portillo's case was sent to the judicial branch; five years later, the Supreme Court ruled that there was no constitutional basis for his refusal to comply with the CMS, even "reasons of conscience or deep conviction," but recognized his right to do so without bearing arms. ${ }^{68}$ This decision sparked an intense debate. Alfredo's parents were "dissatisfied" with the court ruling:

We are unhappy because we believe that no one can be forced in a civilized society ... [Instead,] it would be more beneficial to serve the country by carrying out a service to help others.... Complying with the CMS is objectionable from every point of view, although it tries to appear to be an act of serving the country ... We propose a great national debate, in which all of the sectors involved can participate. ${ }^{69}$

This ruling was not only widely discussed in the media but also aroused great dissatisfaction among the military authorities. Brigadier General William Walter alerted Defense Minister Horacio Jaunarena that "this ruling seriously worries the heads of the Armed Forces General Staff, as it has made individual freedomspecifically 'freedom of conscience'-prevail above the common good of society," and predicted that "if similar cases were to happen in a chain reaction in a not-so-distant future, the military service that citizens provide according to Law 17,531 would be significantly affected." Finally, Walter asked the defense minister to instruct the attorney general, Andrés D'Alessio, to have prosecutors use "any means necessary to prevent the recurrence of a ruling like the above."70

Taking the same position months after the Supreme Court ruling, in July 1989 Colonel Auditor Raúl Edgardo Semberoiz published an article on conscientious objection in the Revista Militar. ${ }^{71} \mathrm{He}$ questioned those who "opposed the obligation to bear arms in defense of the country based on the fact of belonging to the Catholic religion." According to the objectors, conscription "could lead them to violate the commandment "thou shall not kill" " based on "freedom of religion and conscience." Semberoiz argued that "individual rights ... should be legally protected as long as they do not affect the common good, order, and public morality. In this way, these requirements should be privileged to the detriment of the right that is temporarily restricted." He referred to conscientious objectors as "deserters": 
Allowing precedents like that of this young deserter ... to start gaining ground in Argentine justice could leave the inhabitants of the nation ... absolutely defenseless, causing serious harm to the good and order of the community, which must not be attacked by external or internal dangers from an army of young people "armed" with only a court ruling wrapped around their hands. ${ }^{72}$

In asserting a need to avoid precedents that could have a multiplier effect, Semberoiz acknowledged the existence of a broader political movement behind Portillo's struggle that sought to modify the rule and not simply to achieve exceptions. One of his arguments was that military training for "defense" was an important element that, along with others, met the "goal of deterrence" and contributed to "deterring attacks or aggressions of any kind": "We could say that people are taught to use weapons to prevent deaths and not to produce them." Unlike the rest of the exceptions set out in the law, which are "more precise and easy to prove," the "legitimacy" of conscientious objection "is not even legally recognized."

It is precisely this: there is no doubt that every time an objection based on religious grounds is made, the content and scope of this foundation will have to be assessed, because it is not easy simply to accept, as in this case, any fanciful interpretation of a biblical text. ${ }^{73}$

Semberoiz argued that, unlike the "free examination" that the Protestant religions allow, the "Word of God" for Catholics should be "interpreted according to the dictates of the Holy Doctrine." Here he stressed what he described as "an absolute consistency from antiquity to the present": "The Catholic Church clearly explains the commandment 'Thou shall not kill' and admits the existence of self-defense [against the unjust aggressor] and a just war which obviously requires the use of weapons." Therefore, Semberoiz concluded,

it is not logical or consistent or honest to invoke the Catholic religion to escape from the obligation to bear arms ... The Church should submit the petitioner to an ecclesiastical tribunal to determine whether the explicit codes of canon law and the implicit rules of Christian dogma have been violated. ${ }^{74}$

\section{Concluding Remarks}

In this article I have reconstructed the history of FOSMO, an organization created in 1983 to fight Argentina's compulsory military service and uphold the exercise of freedom of conscience. I have shown how Eduardo Pimentel's decision to prevent his son from complying with the CMS (based on the exercise of patria potestad) spearheaded a broader movement that built a network of citizens, parents, and youth; and how, at the same time, it set up a rich conceptual, political, and legal structure to challenge the military conscription system and proposed the implementation of civil/community service as an alternative. Although originally based on moral and religious grounds, the arguments against the CMS garnered support and were mixed with Christian views on violence, the defense of the family, and the patria potestad and with arguments against war and for peace that appealed to human-rights discourse. The appeal to the courts, however, was a way to stave off punishment, and it set a precedent by taking the struggle against conscription outside the military sphere.

The experience of FOSMO also shows how the universe of issues and problems of the human-rights agenda has been incorporated, expanded, analyzed, and legitimized for society in a post-dictatorship framework. FOSMO showed how, from its historic 
origins through its day-to-day operations, the CMS had "nationalized" subaltern groups through a series of disciplinary practices and the inculcation of a warring male morale.

FOSMO's struggle met with strong resistance because it challenged a strongly rooted institution that promoted the socialization of youth (and was highly significant in building their masculinity). The system's critics focused not on its failures but on the logic of operation, values, and practices that organized it. In this sense, FOSMO's struggle jeopardized the ability of the military power apparatus to shape youths par excellence. This helps explain the strong resistance to the implementation of a law contemplating conscientious objection or even the possibility of performing a form of national service without weapons.

\section{Notes}

1. CMS was enacted through Law 4.031 law of 5 December 1901 and was finally abolished by former president Carlos Saúl Menem on 31 August 1994 via Decree 1537. Enlistment in the military is now on a voluntary basis, and women are now eligible to enlist.

2. On Carrasco's death see Jorge Urien Berri and Dante Marín, El último colimba. El caso Carrasco y la justicia arrodillada (Buenos Aires: Planeta, 1995); Mirta Mantarás, Caso Carrasco: un pacto de silencio (Neuquén: APDH Neuquén, 1995).

3. I am grateful to my director, Dr. Sofía Tiscornia, for her comments, and to Pablo Pimentel and his family for their support, affection, and generosity in providing all the material about FOSMO. I wish to thank Alejandro Spoturno, Prof. Pilar Pérez, Dr. Laura Kropff, Laura Pakter, and Luz Rodríguez Penas for their collaboration in the translation process.

4. Sofía Tiscornia, Activismo de los Derechos Humanos y Burocracias estatales. El caso Walter Bulacio (Buenos Aires: CELS-Editores del Puerto, 2008), 201.

5. Ibid., 157.

6. “Una polémica decisión,” La Voz, 18 February 1983, Pimentel family file. Unless otherwise noted, all translations into English are my own.

7. Superhumor (n.d.), Pimentel family file.

8. Ibid.

9. Ibid.

10. “La oposición al servicio militar, a Tribunales," Río Negro, 7 April 1983, Pimentel family file.

11. "Defienden la patria potestad," $L a$ Voz, 8 April 1983, Pimentel family file.

12. Claudia Fonseca and Andrea Cardarello, "Derechos de los más y menos humanos," in Derechos Humanos, tribunales y policías en Argentina y Brasil, ed. Sofía Tiscornia and María Pita, 9-41 (Buenos Aires: Antropofagia, 2005), 10.

13. Teresa Caldeira, City of Walls: Crime, Segregation, and Citizenship (Los Angeles: University of California Press, 2000), 341.

14. Elizabeth Jelin, "La política de la memoria: El Movimiento de Derechos Humanos y la construcción de la democracia en la Argentina," in Juicio, castigos y memorias: derechos humanos y justicia en la política argentina, ed. Carlos Acuña, Inés González Bombal, Oscar Landi, Luis Alberto Quevedo, Catalina Smulovitz, Adriana Vacchieri, and Elizabeth Jelin, 101-46 (Buenos Aires: Nueva Visión, 1995).

15. Ludmila Da Silva Catela, "Desaparecidos e dereitos humanos. Entre um drama nacional e um dilema universal," in Antropología e dereitos humanos, ed. Roberto Kant de Lima and Regina Reyes Novaes, 203-66 (Niterói: Editora da Universidade Federal Fluminenese, 2001).

16. Eduardo Luis Duhalde describes the "terrorist state" as a (new) archetypical state model, characterized by the militarization of the state structure and the use of repressive methods that work to annihilate its opponents as well as to destroy every type of democratic and anti-dictatorial organization. This particular description and characterization of state terror, qualitatively different from any other group in particular, was imposed on the 
attempts to characterize the state's repressive modus operandi during the last dictatorship as a "war against subversion" or a "dirty war." See Eduardo Luis Duhalde, El Estado terrorista argentino. Quince años después, una mirada crítica (Buenos Aires: EUDEBA, 1999).

17. During the 1960s and 1970s, the military and security forces reoriented their activities and proceedings, embracing the DNS, which had originated in North America. They considered that "the enemy could be found in any social environment or situation and conceived of every conflict as an attack or aggression against security and as part of the 'subversive strategy.' At the same time, the Military and Security Forces endorsed the national interest monopoly of the Military Forces." Emilio Crenzel, La historia politica del Nunca Más. La memoria de las desapariciones en la Argentina (Buenos Aires: Siglo XXI, 2008), 28.

18. Pilar Calveiro, Poder y desaparición. Los campos de concentración en Argentina (Buenos Aires: Colihue, 1998), 26-7, explains the change in the repressive modality: "The 1976 coup d'état represented a substantial change: the missing and the concentration and extermination camps stopped being one of the forms of repression to become the repressive modality managed and executed directly by the military institutions. From that moment on, the repressive activity focusing and centering on the jail system became the structure that allowed the systematic disappearance of people, controlled and managed by the military forces."

19. CELS, Conscriptos detenidos-desaparecidos (Buenos Aires: CELS, 1982).

20. María Pita, "Mundos morales divergentes. Los sentidos de la categoría familiar en las demandas de justicia ante casos de violencia política," in Derechos Humanos, tribunales y policías en Argentina y Brasil, ed. Sofía Tiscornia and María Pita, 205-35 (Buenos Aires: Antropofagia, 2006), 207.

21. Ibid.

22. María Pita, "La construcción de la maternidad como lugar político en las demandas de justicia. Familiares de víctimas del Terrorismo de Estado y de la violencia institucional en Argentina," Arenal 8, 1 (2001): 127-54.

23. Carla Villalta, e-mail to the author.

24. Judith Filc, Familia y dictadura (Buenos Aires: Editorial Biblos, 1997), 65.

25. Ibid., 47.

26. Máximo Badaró, Militares o ciudadanos. La formación de los oficiales del Ejército Argentino (Buenos Aires: Prometeo, 2009), 129 and 130.

27. Ibid. 189.

28. Eduardo Pimentel, "Yo intento subvertir las cosas injustas," Río Negro Sunday magazine, 17 April 1983, 4.

29. Ibid.

30. Ibid.

31. “¿Servicio militar obligatorio u obligados sirvientes de los militares?” Siete Días, 14 February 1984, 5.

32. Stojan Tercic, letter, La Nación, 7 September 1983.

33. Fernando Angel Portillo, letter, La Razón, 20 March 1984.

34. Quoted passages in this paragraph are from "FOSMO's Foundations" (November 1983), Pimentel family file.

35. "Hacia el fin del Servicio Militar Obligatorio," Humor, November 1983, 123.

36. "FOSMO's Foundations."

37. Pedro Vendramin, Un derecho todavía violado [A still violated right] (Buenos Aires: FOSMO, 1985).

38. This Argentine term for economically marginalized immigrants from the provinces to the city of Buenos Aires racializes class. See Claudia Briones, La alteridad del "Cuarto Mundo." Una reconstrucción antropológica de la diferencia (Buenos Aires: Ediciones del Sol, 1998).

39. “¿Servicio militar obligatorio u obligados sirvientes de los militares?” Siete Días Magazine, 14 February 1984, 4. 
40. Ibid.

41. Nueva Presencia, 3 August 1984.

42. Pilar Calveiro, Política y/o violencia. Una aproximación a la guerrilla de los años 70 (Buenos Aires: Norma, 2005), 86.

43. Ibid.

44. Ibid., 86-87.

45. Edward Siutti, letter to the editor, Tiempo Argentino, 1 March 1984, 23.

46. Eduardo Pimentel, letter to the editor, Tiempo Argentino, 13 March 1984, 23.

47. Henrietta Moore, "The Problem of Explaining Violence in the Social Sciences," in Sex and Violence: Issues in Representation and Experience, ed. Penelope Harvey and Peter Gow, 138-55 (London: Routledge, 1994), 138.

48. “Conscripción o fuerza de voluntarios," Revista de Educación del Ejército 40 (1983): 4-16, 14.

49. This petition included the fight for freedom of conscience. It stated that the respect for human rights was mandatory in all institutions of the army, security, and intelligence and that the Declaration of Human Rights was to be visible in all establishments.

50. Transcript, from a recording, Pimentel family archive.

51. La vida en un bolillero (FOSMO, July 1986).

52. Ibid.

53. Judith Butler, Vidas precarias. El poder de duelo y la violencia, trans. Fermín Rodríguez (Buenos Aires: Editorial Paidos, 2006).

54. Ibid., 64 .

55. Ibid., 74 .

56. Sabés porqué el Servicio Militar es OBLIGATORIO? (Buenos Aires: FOSMO, 5 July 1985).

57. Ibid.

58. About 10,000 fewer soldiers-20 percent fewer than in recent years, for a total of 25,000 - were to be asked to comply with the CMS in 1986, owing to budget constraints related to, for example, the modernization processes of the armed forces. "Disminuye la incorporación de conscriptos," Clarín, 29 December 1985.

59. "Limitarán la incorporación al servicio militar" (interview with Horacio Jaunarena), La Voz, 25 August 1985, 9.

60. Ibid.

61. Alberto Ferrari, “Objetores de conciencia,” Nuevo Sur, 27 October 1989, 24.

62. Ibid.

63. Ibid.

64. Román Lejtman, "Ni objetores de conciencia ni moros que lloran como mujer," Página 12, 30 September 1989, Pimentel family file.

65. Ibid.

66. Gendered language is often used to order differences in power, with the result that power takes on a sexual connotations in many contexts. Moore, "The Problem of Explaining Violence," 139.

67. Fernando Portillo, "Mi hijo no quería que le enseñanaran a matar...," Ahora, 4 May $1989,33$.

68. “Servicio militar sin armas," La Prensa, 18 April 1985, 6.

69. Portillo, "Mi hijo no quería..."

70. Rodolfo Iribarne, Diario "Ámbito Financiero," Clarín, n.d.

71. Semberoiz was an advisor to the Joint Staff of the Army, professor of international law in the Faculty of Social Sciences at the National University of La Plata, and author of the book Derecho Internacional de Guerra (Buenos Aires: Círculo Militar, 1985).

72. Raul Edgardo Semberoiz, "Los objetores de conciencia," Revista Militar 72 (1989): 60-64, 61.

73. Ibid., 61.

74. Ibid., 63-64. 